\title{
Research on Chinese-Language Curriculum Development in Higher Education from the Perspective of Sociology
}

\author{
Yaqin Hu \\ School of Law, Southwest Petroleum University, Chengdu, China \\ Email: hyq218hyq@163.com
}

How to cite this paper: Hu, Y.Q. (2018) Research on Chinese-Language Curriculum Development in Higher Education from the Perspective of Sociology. Open Journal of Social Sciences, 6, 64-67. https://doi.org/10.4236/jss.2018.612006

Received: November 9, 2018

Accepted: December 14, 2018

Published: December 17, 2018

Copyright $\odot 2018$ by author and Scientific Research Publishing Inc. This work is licensed under the Creative Commons Attribution International License (CC BY 4.0).

http://creativecommons.org/licenses/by/4.0/

\begin{abstract}
A reexamination of Higher Education Curriculum contributes to exploring its social value as an education resource and enhancing the social competence of students. Chinese-language curriculum being a basic curriculum of general education program, fully researching the social value of higher education institution's Chinese-language curriculum is conducive to fostering the technology application skills of students, making it necessary to carry out this research from the perspective of sociology.
\end{abstract}

\section{Keywords}

Sociology, Chinese-Language, Talent Cultivation

\section{Introduction}

Practical education has been given more and more emphasis with educational and teaching philosophy witnessing continuous innovation and reform. The society serves as the main fronts of making educational and teaching innovation, making it necessary to combine teaching process with the society and carries out practical education based on social requirements. As an important part of higher education process, Chinese-language curriculum teaching should be further innovated under the guidance of sociology, in the background of further developing education.

\section{Cultivation of Applied Talents in Higher Education}

Applied talents are talents equipped with practical application abilities. The mode of applied talents teaching is designed to help students improve their knowledge structure and enhance their competence in all aspects, with the ob- 
jective of fostering the practical applied abilities of students. Available in many higher education institutions, Chinese language major serves to carry over the profound Chinese culture; whereas, Chinese language teaching encountered many challenges mainly resulting from the following two aspects. First, the teaching philosophy of some teachers are too traditional to give full play to the advantage of Chinese language major [1]. Second, the academic teaching mode, still prevalent in some higher education institutions, lacks scientific tertiary structure for nurturing students, thus affecting and restricting students nurturing quality.

Higher education institutions can have a new perspective of Chinese-language teaching with more application of sociology and interactionism, which studies how different social groups interact with each other. In teaching process teachers and students communicate and interact with each other as different social groups. Higher education institutions are expected to cultivate such students that can adapt to the social situation with a sense of collectivism. When it comes to Chinese-language curriculum, higher education institutions should analyze the challenges encountered by Chinese-language teaching based on the social values and social requirements for talents.

It is apparent that applied talents nurturing has become the future objective of higher education and the goal of higher education reform and innovation. Applied talents nurturing can be achieved by working on the following three aspects. First, higher education institution should spare no efforts to provide comprehensive education featured with knowledge, skills and quality rather than knowledge only and cultivate students into versatile talents in a multi-disciplinary way by transforming their professional skills into comprehensive skills. Second, higher education institutions should give more priority to skills training of students, especially applied abilities. Last but not least, higher education institutions should lay more emphases on building up the innovative capacity of students by consolidating their knowledge structure, raising their awareness of innovation and cultivating their personality.

\section{Chinese-Language Curriculum Development in Higher Education from the Perspective of Sociology}

Chinese-language curriculum development in higher education from the perspective of sociology also reflects the importance attached to culture during teaching process.

\subsection{Combine Local Culture with Perception of Time}

Another important research aspect of sociology is how local culture are created. Evolving along with time, local cultures are considered as an important part of culture that can reflect social and historical patterns. For example, the poem "Thinking of My Brothers on the Double Ninth Day" expressed how much the poet missed his brothers on the Double Ninth Day, which is a traditional holiday 
for the elderly because the Chinese word for "nine" is a homophone for "long".

Nowadays with accelerating pace of life, a lot of people have even forgotten the cultural implications of traditional festivals like Double Ninth Festival. By exploring local culture, higher education institutions can help students recall outstanding traditional Chinese culture and appreciate the profound Chinese culture, so as to raise their awareness of traditional Chinese culture with the help of the perception of time.

\subsection{Broaden the Horizon of Students}

Culturally speaking, space and time correspond to each other. Since space is a must for people's daily life, higher education institutions can broaden the horizon of students by integrating the perception of space in cultural materials into teaching materials. For example, the fable, named as "glancing at the sky from the bottom of the well' by Chuang Tzu, demonstrates that one should not take a closed-door policy in the big world, thus making students realize how small they are in the vast universe. In this way, higher education institutions can teach students to view the world and life with broader outlook.

From the perspective of sociology, people with differential patterns interact with each other based on their personal morality derived from their differential patterns. Chinese-language teaching can help students form comprehensive personalities by instilling the Chinese traditional cultural values of benevolence, righteousness, courtesy, wisdom and loyalty into their mind with Chinese traditional cultural materials like Chinese classic literature [2]. In this way, higher education institutions can help students from a more comprehensive personality by inspiring students to examine themselves with Chinese cultural essence.

\subsection{Emphasize Interpersonal Communication and Interaction}

Interpersonal communication and interaction is an indispensable part of human life, so higher education institutions should lay sufficient emphases on nurturing relevant skills of students. Some Chinese-language teaching materials refers to human-to-human relations by mentioning human-to-animal relations. For example, the popular fairy tale Mr. Dongguo and the Zhongshan Wolf deals with the ingratitude of the Zhongshan Wolf after being saved by Mr. Dongguo to illustrate how naïve people like Mr. Dongguo will get into trouble for being soft-hearted to evil people. There exist in Chinese classic literatures many similar Chinese fairy tales or fables demonstrating how civil society understand certain phenomenon or issues [3]. Chinese-language teaching can help students develop correct concept of interpersonal communication by integrating similar material into teaching materials.

\section{Conclusion}

To sum up, with increasingly high social expectations of talents, Chinese language teaching should strive to cultivating students with comprehensive compe- 
tence under the guidance of sociology and according to the social requirements of students.

\section{Conflicts of Interest}

The author declares no conflicts of interest regarding the publication of this paper.

\section{References}

[1] Yang, P.Y. (2017) Reflecting upon Construction of the Cultivation Mode of Chinese Language Talents. The Farmers Consultant, 35, 99-100.

[2] Liu, P. (2014) The Interpretation of Local Culture in Chinese Textbooks from the Perspective of Sociology. Bulletin of Chinese Language Teaching: D (Academic), 770, 79-80.

[3] Yao, W.M. (2013) A Probe into the Effective Means of Reformation in Journalist Training Modes at Universities: A Case Study of Neijiang Normal University. Journal of Neijiang Normal University, 28, 93-95. 